\title{
Reading Experiences on the Personal Exploration of Reading Histories of Students of FKIP Universitas Riau
}

\author{
Syofia Delfi \\ Universitas Riau \\ Pekanbaru, Indonesia \\ syofia_delfi@yahoo.com
}

\begin{abstract}
Students' reading experiences are meaningful to be explored in order to attract their interest in reading. This study aimed to explore how the English department students of FKIP Universitas Riau experienced reading based on Exploring Personal Reading Histories. It was a case study and the data were collected through the document of the students'reading histories. The result of this study found that the English Department students of FKIP Universitas Riau experienced reading by reading through pictures in childhood and by reading stories in the first language. In reading English texts, they experienced reading by understanding words, rereading the texts, reading a lot of reading materials, sharing others, and reading for entertainment and knowledge. This study suggests that students need to be facilitated to explore their personal reading histories as an alternative way to attract their reading interest. This study only focused on the students who categorized as the most successful students in Reading courses and in presenting their exploration. Therefore, similar areas for further researches are expected to include the most unsuccessful students in Reading courses and in presenting their exploration.
\end{abstract}

Keywords-reading, reading experiences, and exploring personal reading histories

\section{INTRODUCTION}

Reading is one of the language skills that students majoring in English experience through contexts and processes. Reading experiences are useful for them to attract their interest to do reading. They can read intensively and extensively in Reading courses in order to be competent. They learn how to read and to do practices, exercises, and assignments in Reading courses. Activities dealing with reading are also conducted in order to attract the students' interest.

In English Study Program FKIP Universitas Riau, students learn reading in Reading courses which are classified into; Reading I, Reading II, Reading III, and Extensive Reading. The focus for Reading I, Reading II, and Reading III is intensive reading. While the focus of Extensive Reading course is for reading extensively. Bumford and Day $(1998,2004)$ point out that extensive reading is an approach to language teaching in which learners read a lot of reading materials. The objective of Extensive Reading course is to develop the students' interest in reading by reading a lot of reading materials out side of the classroom. The goal of extensive reading program is to convince students of its value so that they will continue reading extensively on their own after the class is over [1]. It means that Extensive Reading course is an appropriate reading activity to attract the students' interest in reading.

Based on my experience in teaching Extensive Reading, I realize that students need to be involved in various classroom activities. It is needed in order to attract their interest in reading outside of the classroom. It is due to the fact that it is difficult for some of students to be interested in reading; especially, doing reading outside of the classroom; not in the classroom. It shows that they have different reading background which means that they experience different reading histories. Few students perform their report of texts read outside of the classroom spontaneously, some students will perform their report if they are pointed to do it, and some students are not ready to present their report. It shows that lecturers need to be involved in the activity that makes them attract their interest. It is not only in the form of suggestion and direction but also in creating classroom activities.

One of the classroom activities in Extensive Reading course is Exploring Personal Reading Histories [2]. This activity provides the students to recall their reading experiences in which the experiences contribute to their reading competency. The students will perceive the experiences in order to be competent in reading. The experiences are processes supported by environment, contexts, and reading materials. These experiences may or may not attract their interest to do reading. Experiences make the students realize that doing reading is based on interest. It will convince them that by reading, they will know what they should know. They can make it in the activity of Exploring Personal Reading Histories.

To my experience, Exploring Personal Reading Histories was conducted at the second meeting in Extensive Reading course. The class was begun by presenting the exploration of my personal reading histories as a role model for students, then, each student explored their personal reading histories. I noticed that the students were enthusiastic to explore their personal reading histories. The affect of extensive reading activities have a positive 
influence on students' reading proficiency and their intrinsic motivation [3]. However, this study only focused on one of activities in Extensive Reading course. It explored the students' experiences based on their report in Exploring Personal Reading Histories. Therefore, this research answered a question: How did the English Department students of FKIP Universitas Riau experience reading based on their report in Exploring Personal Reading Histories?

\section{REVIEW OF RELATED THEORIES}

Theory relating to this study mainly refers to theory of Reading including Extensive Reading which focuses on Exploring Personal Reading Histories as a classroom activity in Extensive Reading.

\section{Reading}

Reading is a process of readers combining information from a text and their own background knowledge to build meaning [4]. In order to gain meaning from texts, readers face processes. The processes of second language reading can be classified into interactive process, purposeful process and critical process [5]. Interactive process is in terms of schematic knowledge and language knowledge. In schematic knowledge, texts will activate readers' prior knowledge by reading words or phrases in texts. Readers will write what they remember about texts. On other hand, the language knowledge is in terms of decoding words and grammatical structure quickly and accurately. Reflecting in the ways of interactive process, readers present their prior knowledge in pre reading and recall the content of the text by writing what they understand. They write the content of the text by using their own words. Before gaining the meaning of texts, readers should be competent in the language knowledge, like vocabulary and syntactic structures. The competence in language knowledge is for schematic knowledge. Consequently, interactive process makes readers interact with writers through the process of finding the meaning or understanding texts.

The second process skills as Hedge means is purposeful process [5]. In this process, readers do some activities or have reading styles in order to be competent in reading skills. The activities that readers do while reading suggested by Hedge are getting information, responding to curiosity about a topic, following instructions to perform a task for pleasure, amusement, and personal enjoyment. He points out that readers will be directed to the idea contained in texts when they do reading through these activities. Reading styles means are receptive reading, reflective reading, or intensive reading [5]. He points out that readers will be directed to the idea contained in the text when they do reading through these activities. Readers who know what they should do in the process of reading will read texts effectively, for instance, readers who have ability in scanning do not have to read every single word and line. Texts are skimmed for getting the general idea. However, readers' concern in scanning or skimming texts depends on the kinds of texts and the information they want to get from the text whether they read for general idea or specific information. Readers may find the general information, detail information or the information of the whole information of the text. The information that readers gained through the activities will develop their critical thinking. Critical process is shaped through the readers' perception toward ideology and unfamiliar cultural values of texts [5]. The readers' language awareness is as the basic for critical thinking. Therefore, in the critical process, readers need to have careful analysis of the writer's language. Readers' analysis to the writers' language provide the readers in understanding the use of language.

Learners in the reading process bring their own cultural and linguistic background [1]. Factors influencing learners' schemata are the influences of family and society, school influences, and types of readers' schemata. Family or home environment is as a primary source of background knowledge and schemata formation in reading. Family and society or community attitudes vary in diffrent culture. Schools may make students involve in doing activity and reading atmosphere. Practices in reading that children face in their life affect on the type of their schemata. The types of schemata that learners have like linguistic schemata, formal schemata, and content schemata. Learners may gain such schemata based on the oral practice that they experience while learning reading, If the children are exposured to listen the story read to them, they are prepared to listen to how the stories are constructed. They will know that stories are presented in chronological order, problem, solution, and specific characters. By listening to strories, children gain life experience. This experience matches to what they acquire about other kinds of texts like recipes, newspaper column, research papers, and lab report. Any texts readers read is as the background knowledge for the learners to read the following texts. The different learners' schemata indicates that they are individual. The difference refers to different motivation, learning styles, and learners' strategies. Different learners' cultural and linguistic background affect their understanding on the texts they read. reading success is governed by the competencies of visual information extraction and prior knowledge consolidation.

Students are expected to be able to find particular information or the general idea of what the text is about. It depends on the information that readers want to find out whether they read for specific information or for general idea or both of them. Generally, students read both of these informations in learning. It means that they practice from time to time to find these informations. Consequently, they have the skill how to find specific information and the skill in finding the general idea. Finding general idea refers to skimming and finding specific information [6]

EFL learners will gain the meaning and acquire the language by reading [5]. It is in line with Harmer who points out that reading is an appropriate activity in acquiring the language [6]. It means that reading contributes to vocabulary and grammar. It indicates that by understanding the language components, students will get the meaning of 
texts because the meaning of texts is constructed by language components. In other words, readers will understand texts based on their understanding on the language components as well as understanding text construction. Readers will absorb a good source of writing because they can learn vocabulary, sentences, and text organization [7]. The study found that syntactic knowledge as important as vocabulary knowledge on second language reading comprehension [8]. Although both vocabulary knowledge and syntactic knowledge are important, they had different result in terms of the affect on the participants' reading comprehension. However, the syntactic knowledge was not an element that affects the participants' reading comprehension. On other hand, the participants who had better language proficiency tended to utilize more literacy skills or prior knowledge and schemata skills, to interpret the content of reading passages that the lower language proficiency students. This study suggested that the students are provided with communicative learning environment in order to have opportunities to practice vocabulary knowledge and syntactic knowledge

\section{Extensive Reading}

Extensive reading is an approach of the language teaching in which learners read a lot of easy material in the new language by choosing their own reading material for overall meaning, information and enjoyment [2]. Extensive reading is reading of longer passages with focus on enjoyment and or learning new information while reading [4]. Reading with enjoyment direct readers to gain the information in the process of reading until they finish reading texts. It will make them continue reading the longer texts or the other texts.

The characteristics of extensive reading are (1) The reading materials is easy, (2) A variety of reading material on a wide range of topics is available. (3)Learners chose what they want to read, (4) Learners read as much as possible, (5) Reading speed is usually faster than slower, (6) The purpose of reading is usually related to pleasure, information, and general understanding, (7) Reading is individual and silent, (8) Reading is its own reward, (9) The teacher orients and guides the students, (10) The teacher is a role model of a reader [2, 9]. These characteristics are always as references used by writers and researchers in discussing or studying extensive reading.

In order to gain the goal of extensive reading program, teachers need to know how extensive reading program is designed and implemented. Five points for designing and implementing extensive reading approach [1]. They suggest that teachers get students on board, provide access to reading materials, help students find and select appropriate materials, design class activities; and develop accountability or evaluation mechanism. In preparing students to work in extensive reading program, teachers are expected to make them perceive that doing extensive reading is as a pleasure activity. Students are guided to decide reading materials they read in terms of number, kinds, ways and goals of reading. They suggest that in the beginning of the course, teachers can ask students to have a short presentation for summarizing research on the benefits of extensive reading. Hence, in the process of the course, teachers can show students the benefits of extensive reading explicitly and implicitly by talking about what they have done with the interesting reading materials they have selected. Students may share the reading materials they have read through presentations, discussions, posters, and recomendation forms. Teachers need to consider the reading materials used in extensive reading. Hedgcock and Ferris (2009) suggest that teachers are expected to provide materials which are appropriate for students' interest, language proficiency, and literacy skills.

The use of extensive reading in improving EFL learners' reading for non English major in Taiwan [10]. The study proved significantly higher reading level gained by the treatment group. The study suggested that utilizing extensive reading can provide a successful alternative to improve Asian learner's reading levels as well as considering pedagogical suggestion in implementing extensive reading. Sarwo Edy studied the effectiveness of extensive reading on the Indonesian students' reading comprehension achievement and motivation. The study proves that students taught by the extensive reading activity showed higher scores than those taught by conventional way; however, there is no interaction between students' motivation and extensive reading [10]. The practice on extensive reading in this study was only for reading course in which the goal is for comprehension. Sarwo Edy suggested make special course for extensive reading in order to enhance the students' reading skills and reading habit. On other hand, Ho-Hyuk Jang et al studied the effect of English extensive reading activities on the students' reading proficiency and reading motivation in Korea [3]. The study found that extensive reading activities have a positive influence on students' reading.

\section{Exploring Personal Reading Histories}

Exploring Personal Reading Histories is one of the activities in Extensive Reading course. It is a classroom activity in which students discuss the past and present role of reading in their lives [2]. The learners can evaluate their reading experiences, habits, and attitude in the first and the foreigh language. The components to be considered in implementing Exploring Personal Reading Histories. The components are levels, aims, preparation, and variations referring to questions as guidances as the table 1 .

Table 1: The Components of Exploring Personal Reading Histories

\begin{tabular}{|l|l|l|}
\hline No. & Components & \multicolumn{1}{c|}{ Description } \\
\hline 1. & Level & Intermediate \\
\hline 2. & Aim & $\begin{array}{l}\text { To develop students' awareness of } \\
\text { the role of reading in their lives }\end{array}$ \\
\hline
\end{tabular}


Table 1. Cont

\begin{tabular}{|c|c|c|}
\hline 3. & Preparation & $\begin{array}{l}\text { Select some appropriate questions } \\
\text { and teachers play as a role model. } \\
\text { Example of Questions: } \\
\text { 1. What are your first } \\
\text { memories of reading? } \\
\text { 2. Did anyone read to you? If } \\
\text { so, who? I not, why was } \\
\text { that? } \\
\text { 3. What ideas of things did } \\
\text { you enjoy reading most? } \\
\text { 4. Do you still enjoy reading } \\
\text { these kinds of things } \\
\text { today? If not, how has } \\
\text { your reading changed? } \\
\text { 5. Which author or types of } \\
\text { reading have been most } \\
\text { important to you? } \\
\text { 6. What role does reading } \\
\text { play in your life now (for } \\
\text { example, as a parent or for } \\
\text { work, pleasure, } \\
\text { community, or religious } \\
\text { purposes? }\end{array}$ \\
\hline 4 & $\begin{array}{l}\text { Various } \\
\text { questions }\end{array}$ & $\begin{array}{l}\text { Questions are taken home questions } \\
\text { and the responses will be presented } \\
\text { in the classroom. }\end{array}$ \\
\hline
\end{tabular}

These components were considered in designing Exploring Personal Reading Histories in Extensive Reading course. Therefore, the analysis was also based on the components of research questions.

\section{METHOD}

The suitable design in answering the research question of this study is a qualitative research approach, specifically, it is a Case Study. A Case Study focuses on instances of a particular phenomenon to provide an in-depth account of the event, relationships, experiences or processes occurring in the particular instance [12, 13]. This study focuses on the detail explanation on how the English department students of FKIP Universitas Riau experienced reading based on the exploration of their personal reading histories.

The participants in this study were purposively chosen. They were semester five students of the English Study Programme FKIP, Universitas Riau taking the Extensive Reading course. These students were selected based on several criteria. The first criterion was the students who got the highest score in Reading courses (Reading I, Reading II, and Reading III). The second criterion was the students who reported the exploration of their personal reading histories fluently as well as in responding questions and comments. The students who met these criteria were two persons. They were Anita (pseudo name) and Ermita (pseudo name). The instruments determined appropriate for this current Case Study was the document of the learners' exploration of personal reading histories. The document of exploration of personal reading histories of Anita and Ermita was analyzed. A constant comparative analysis was carried out in which the document was read and reread to code participant's responses and classifications [11].

\section{FINDING AND DISCUSSION}

The data gained from the instrument of this study was analyzed in terms of Anita's and Ermita's reading experiences. It was classified based on Anita's and Ermita's responses on the questions for Exploring Personal Reading Histories. Then, it was classified into themes for the answer of the research question. The analysis for the classification of the themes based on the answer of the the questions is as examples in following tables.

Table 2: The Analysis for Themes (Open Coding) for Exploring Reading Histories of English Department Students of FKIP Universitas Riau

\begin{tabular}{|c|c|c|}
\hline Questions & Responses & Themes \\
\hline $\begin{array}{l}\text { What are } \\
\text { your first } \\
\text { memories of } \\
\text { reading? }\end{array}$ & 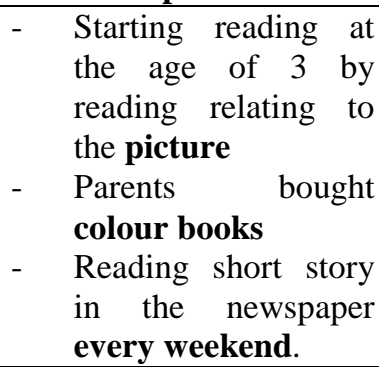 & $\begin{array}{c}\text { Every } \\
\text { weekend }\end{array}$ \\
\hline $\begin{array}{l}\text { What are } \\
\text { your first } \\
\text { memories of } \\
\text { reading } \\
\text { English? }\end{array}$ & $\begin{array}{l}\text { - Understanding texts } \\
\text { by rereading. } \\
\text { - Sharing others about } \\
\text { what they read. } \\
\text { - Writing words } \\
\text { learnt }\end{array}$ & $\begin{array}{c}\text { Rereading } \\
\text { Shared } \\
\text { Writing words } \\
\text { learnt }\end{array}$ \\
\hline
\end{tabular}

The result of the analysis of Themes (Open Coding) for Exploring Reading Histories of English Department Students of FKIP Universitas Riau is as the following table.

Table 3: Themes (Open Coding) for Exploring Reading Histories of English Department Students of FKIP Universitas Riau

Picture, Colour books, Bought colour books, Pronouncing letters, Reading newspaper, Reading short stories every weekend, Guessing the meaning, Reading loudly and consulted dictionary, Writing words learnt, Guessing the appropriate answers, Reading many English texts, Rereading, Novels and interesting books, Sharing, Novels and interesting books, Entertainment and knowledge

The result of the analysis shows meaningful experiences in Anita's and Ermita's reading histories. They 
began to read by reffering to pictures. Besides, they were also supported in childhood as well as did practices and efforts in the process of reading and after reading English texts. They read colour books provided by their parents. They stated "Parents bought colour books." (Document of exploration) It shows that it influences the learners' schemata about reading. It is as what Hedgcock and Ferris (2009) believes. They state that family is one factors influencing learners' schemata. They also claim that family or home environment is as a primary source of background knowledge and schemata formation in reading.

The result of analysis also shows the affect of reading through pictures. They said that they read newspaper and stories every week. Children practice reading in their life affect on the type of their schemata [1]. The types of schemata that learners have like linguistic schemata, formal schemata, and content schemata. These are the students' experience about how they began and enjoyed reading in the first language. Their interest to do reading also made them read on purpose. They read in order to know what texts are about. Since they read in the language they learnt, the students had effort to understand texts. It indicates that it was as a reflection in learning languages. The study found that syntactic knowledge is as important as vocabulary knowledge on second language reading comprehension [8].

The learners experienced reading materials by understanding words; meaning and pronunciation. They guessed the meaning of words. They read texts loudly and wrote the words learnt. They reread the texts to make sure what they understood. They read a lot of English texts. They shared what they read. They read novels and interesting books indicating that they read for entertainment and knowledge. The meaning occurs starting from words to texts, the meaning is constructed starting from rules to semantic, the meaning is found starting from indentifying purpose to scanning, and the meaning is formulated in the forms of literal and implied meaning. Students can gain the meaning if they do reading based on interest like doing extensive reading [14]. Moreover, it will increase their reading proficiency. It is in line with Ho- The study found that extensive reading activities have a positive influence on students' reading [3].

How the English Department students of FKIP Universitas Riau experience reading based on their report in Exploring Personal Reading Histories can be illustrated from the following figure.

\section{Reading Experiences the English Department students of FKIP Universitas Riau based on their Report in Exploring Personal Reading Histories}

\begin{tabular}{|c|c|}
\hline $\begin{array}{l}\text { Reading in the } \\
\text { First Language } \\
\text { - Reading } \\
\text { through } \\
\text { pictures } \\
\text { - Reading } \\
\text { stories }\end{array}$ & $\begin{array}{l}\text { Reading English Texts } \\
-\quad \text { Efforts to understand } \\
\text { texts } \\
\text { - } \quad \text { Reading a lot of reading } \\
\text { materials } \\
-\quad \text { Sharing others } \\
-\quad \text { Reading for } \\
\quad \text { entertainment }\end{array}$ \\
\hline
\end{tabular}

The figure shows that the English department students of FKIP Universitas Riau experienced reading based on their report in Exploring Personal Reading Histories by reading through pictures and by reading stories in the first language in childhood. In reading English texts, they tried to understand words if they do not know the meaning. They reread the texts to convince themselves whether they really understood or not. If they really understood what they read, they would share others. They always read a lot of reading materials. They also did reading for entertainment and knowledge. These experiences show the answer of the research question of this study "How did the English Department students of FKIP Universitas Riau experience reading based on their report in Exploring Personal Reading Histories?"

The finding of this study is based on classroom activities of Extensive Reading in which they told about their reading experiences. It seems that the students felt free to tell about their experiences. Their childhood reading experiences in the first language are really beneficial for their interest. They were introduced to reading activities through something interesting for children which were pictures. Understanding reading materials based on pictures trained the students to find what the pictures mean for what the texts were about. Their premilinary experiences in reading were maintained by reading stories. These experiences may attract their intrinsic motivation to do reading. They evaluate their reading ability and it can make them realize the need of reading. Moreover, it can attract their intrinsic motivation to do reading. Therefore, it is not a big deal for them to do effort in understanding English texts. They experienced reading by understanding words and rereading the texts. They also read a lot of reading materials and shared others as well as reading for entertainment and knowledge.

These experiences will not be noticed by lecturers if the students are not provided with the activity in exploring their personal reading experiences. By doing this activity, the students are facilitated to recall what they actually experienced dealing with reading. They will evaluate their own reading ability and their reading activity. They can make it if they realize about the need of reading. Therefore, it is expected that Extensive Reading lecturer implement Exploring Personal Reading Histories as one of classroom activities. Each student may inspire one to another to develop their reading activity for reading ability because every body in the classroom listening every body telling Personal Reading Histories. However, this study only focused on the students who were categorized as the most successful students in Reading courses and in presenting the exploration of their personal reading experiences. It is much better if the participants also include the most unsuccessful students in Reading courses and in presenting their exploration. Researchers will perceive the use of including Exploring Personal Reading Histories as one of classroom activities in Extensive Reading course. They can see the 
different experiences, practice, interest, attitude, expectation, and motivation.

\section{CONCLUSION AND RECOMMENDATION}

This case study explored how the English Department students of FKIP Universitas Riau experienced reading based on their report in Exploring Personal Reading Histories. The finding shows that the English department students of FKIP Universitas Riau experienced reading by reading through pictures in childhood and by reading stories in the first language. In reading English texts, they read by understanding words, rereading the texts, reading a lot of reading materials, sharing others, and reading for entertainment and knowledge. The major point of this study was about the students' reading experiences based on Exploring Personal Reading Histories in which it was a classroom activity in Extensive Reading. The students felt free to tell about their experiences. They evaluate their reading ability and it can make them realize the need of reading. Moreover, it can attract their intrinsic motivation to do reading. This current study offers suggestive evidence for attracting the students' reading interest. By conducting the similar study, it can facilitate the students to explore their reading experiences. However, this study only focused on the students who categorized as the most successful students in Reading courses and in presenting the exploration of their personal reading experiences. Therefore, similar areas for further researches also include the most unsuccessful students in Reading courses and in presenting their exploration about personal reading histories.

\section{References}

[1] Hedgcock. S. J. and Ferris R. D. Teaching Readers of English, Students, Texts, and Contexts, Routledge, New York. 2009.

[2] Bumford, J. and Day, R. R. Extensive Reading Activities for Teaching Language. Cambridge University Press. UK. 2004.

[3] Ho-Hyuk Jang, Mun-Koo Kang, and Young-Hee Kim. Advanced Science and Technology Letters, Vol. 92 (Education 2015) pp. 92-95, ISSN: 2287-1233 ASTL. 2015.

[4] Anderson, J. N. and Nunan, D. Practical English Language; Reading. Mc Graw-Hill ESL/ELT. New York. 2008.

[5] Hedge, T. Teaching and Learning in the Language Classroom. Oxford University Press. New York. 2007.

[6] Harmer, J. How to Teach English. Pearson Education Limited. England. 2007.

[7] Lee, S.Y. and Hsu. Determining the Crucial Characteristics of Extensive Reading Program; the Impact of Extensive Reading on EFL Writing. International Journal of Foreign Language Teaching, 5 (1), 12-20. 2009.
[8] Kuang Yu Chen. Vocabulary, Syntactic Knowledge and Reading Comprehension: the Perspective of College Students. WHAMPOAAn Interdisciplinary Journal 66 (2014) 39-52. 2014.

[9] Bumford, J. and Day, R. R. Extensive Reading Activities in the Second Language Classroom. Cambridge University Press. UK. 1998.

[10] Sarwo Edy. The Effectiveness of Extensive Reading on Students' Reading Comprehension Achievement as Observed from Students' Motivation. Jurnal Pendidikan Humaniora. Vol.2, No. 2, Hal 54-58. 2014.

[11] Flick, U. An Introduction to Qualitative Research. SAGE Publication, Ltd. London. 2007.

[12] Denscombe, M. The Good Research Guide. Open University Press. NewYork. 2007.

[13] Benard, R.H. and Ryan, W.G. Analyzing Qualitative Data; Systematic Approach. SAGE Publication, Inc. California. 2010.

[11] Flick, U. An Introduction to Qualitative Research. SAGE Publication, Ltd. London. 2007.

[12] Denscombe, M. The Good Research Guide. Open University Press. NewYork. 2007.

[13] Benard, R.H. and Ryan, W.G. Analyzing Qualitative Data; Systematic Approach. SAGE Publication, Inc. California. 2010.

[14] Brown, H. D. Teaching by Principles an Interactive Approach to Language /Pedagogy. Pearson Education Inc. New York. 2001. 